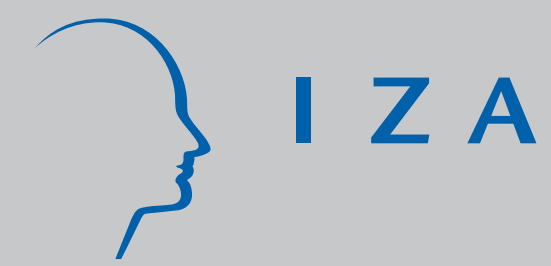

IZA DP No. 1557

Immigrants' Responsiveness to Labor Market Conditions and Its Implications on Regional Disparities: Evidence from Spain

Catalina Amuedo-Dorantes

Sara de la Rica

April 2005 


\title{
Immigrants' Responsiveness to Labor Market Conditions and Its Implications on Regional Disparities: Evidence from Spain
}

\author{
Catalina Amuedo-Dorantes \\ San Diego State University \\ Sara de la Rica \\ Universidad del País Vasco \\ and IZA Bonn
}

Discussion Paper No. 1557

April 2005

IZA
P.O. Box 7240
53072 Bonn
Germany

Phone: +49-228-3894-0

Fax: +49-228-3894-180

Email: iza@iza.org

\begin{abstract}
Any opinions expressed here are those of the author(s) and not those of the institute. Research disseminated by IZA may include views on policy, but the institute itself takes no institutional policy positions.

The Institute for the Study of Labor (IZA) in Bonn is a local and virtual international research center and a place of communication between science, politics and business. IZA is an independent nonprofit company supported by Deutsche Post World Net. The center is associated with the University of Bonn and offers a stimulating research environment through its research networks, research support, and visitors and doctoral programs. IZA engages in (i) original and internationally competitive research in all fields of labor economics, (ii) development of policy concepts, and (iii) dissemination of research results and concepts to the interested public.
\end{abstract}

IZA Discussion Papers often represent preliminary work and are circulated to encourage discussion. Citation of such a paper should account for its provisional character. A revised version may be available directly from the author. 


\title{
ABSTRACT \\ Immigrants' Responsiveness to Labor Market Conditions and Its Implications on Regional Disparities: Evidence from Spain
}

\begin{abstract}
Using data from the Spanish Labor Force Survey (Encuesta de Población Activa) from 1999 through 2004, we explore the role of regional employment opportunities in explaining the increasing immigrant flows of recent years despite the limited internal mobility on the part of natives. Subsequently, we investigate the policy question of whether immigration has helped reduced unemployment rate disparities across Spanish regions by attracting immigrant flows to regions offering better employment opportunities. Our results indicate that immigrants choose to reside in regions with larger employment rates and where their probability of finding a job is higher. In particular, and despite some differences depending on their origin, immigrants appear generally more responsive than their native counterparts to a higher likelihood of informal, self, or indefinite employment. More importantly, insofar the vast majority of immigrants locate in regions characterized by higher employment rates, immigration contributes to greasing the wheels of the Spanish labor market by narrowing regional unemployment rate disparities.
\end{abstract}

JEL Classification: J61

Keywords: international migration, immigrant workers, immigrant location, immigrant responsiveness, labor market conditions, regional disparities

Corresponding author:

Sara de la Rica

Facultad de Ciencias Económicas y Empresariales

Avenida Lehendakari Aguirre, 83

48015 Bilbao

Spain

Email: jeprigos@bs.ehu.es 


\section{Introduction}

Since the 1990s, the Spanish economy has been characterized by a continuous growth in immigration flows from African, Latin American, and European countries. As of today, it is estimated that approximately 1,647,011 foreigners reside legally in Spain (almost 4 percent of the whole population—about 24 percent more than a year ago), most of them living in the communities of Catalonia, Madrid, Andalusia, Region of Valencia and Canary and Balear Islands. The continuous growth in immigration of the nineties coexisted with a decrease in net inter-regional flows despite the persistence of high unemployment rates and important regional differentials. We know through previous work by Bentolila and Blanchard (1990), Bentolila and Dolado (1991), Bentolila (1997, 2002) and Bover and Velilla (1999) that high unemployment rates are the main reason behind the observed decline in inter-regional migration. However, what are the reasons for the experienced increase in immigrant flows? Do immigrants respond to labor market opportunities more than natives and, if so, to what extent do these labor inflows help reduce regional labor market disparities? In other words, does immigration grease the wheels of the labor market in the Spanish case?

In this paper, we use data from the Spanish Labor Force Survey (Encuesta de Población Activa) for 1999 through 2004 to first examine immigrants’ responsiveness to regional employment opportunities relative to natives and, as such, better understand their migratory patterns relative to natives. Given immigrants' heterogeneity depending on their country of origin, we also examine the relative responsiveness to labor market conditions of three major groups of Spanish immigrants: Africans, Europeans, and Latino Americans, separately. Additionally, we explore whether immigrants’ responsiveness to regional employment opportunities varies depending on their time of residence in Spain, with more 
recent immigrants exhibiting a smaller sensitivity to labor market conditions than less recent migrants. Lastly, we analyze whether these new immigration flows have helped reduce regional unemployment disparities and, if so, in which direction and to what extent.

As noted by Borjas, Freeman and Katz (1996), Borjas (2001), Card (2001) and more recently Borjas (2003), “area-approach” analyses relating regional immigration flows to regional employment opportunities via regression-based analyses are inappropriate because (i) they fail to account for forces, other than immigrant flows, affecting immigrants’ location decisions, and (ii) they do not take into account the fact that natives may also be "voting with their feet”. Therefore, using skill groups defined for each year and region as our units of observation so as to partially account for some of the aforementioned forces, we construct indexes capturing the relative supply of immigrants to natives used as our dependent variables in examining the relative responsiveness of immigrants to regional labor market conditions.

Due to the lack of adequate wage data and the high unemployment rates endured by the least skilled and some of the Spanish regions, we rely on employment measures as more suited indicators of labor market prospects. This is especially true in the case of immigrants, for whom accessibility to any type of employment may be crucial for their immediate economic survival. We thus capture work prospects with regional employment rates for each skill group. However, these regional employment rates may be crude indicators of immigrants' employment possibilities in Spain. Therefore, we also use the predicted probability of finding a job as an indicator of individual level employment opportunities. Moreover, given the widespread use of fixed-term and informal work arrangements as well as immigrants' reduced employment stability relative to their native counterparts (Bentolila 1997, 2002; Del Boca and Venturini 2003), we also use information on the predicted probability of finding different types 
of wage and salary jobs, such as indefinite or fixed-term jobs, jobs lacking a formal work contract (or informal jobs), or even self-employment.

We hypothesize that immigrants are more responsive than natives to regional employment opportunities given their lower migration costs across Spanish regions relative to natives. Why should we care about immigrants' responsiveness to regional labor market conditions relative to their native counterparts? Because, if immigrants are more responsive than natives to regional employment prospects, immigration could play a crucial role in reducing regional unemployment disparities given natives’ limited internal mobility.

Our results indicate that immigrants choose to reside in regions with larger employment rates and where their likelihood of finding a job is higher. African and Latin American immigrants appear generally more responsive than their native counterparts to larger employment rates as well as to a higher likelihood of informal, self, or indefinite employment. In contrast, European immigrants are only more responsive than their native counterparts to a higher likelihood of informal and indefinite employment. More importantly, insofar the vast majority of immigrants locate in regions characterized by higher employment rates, immigration appears to be contributing to narrowing regional unemployment rate disparities despite its yet recent character.

In what follows, we first discuss some of the features of the Spanish labor market, such as its recent immigration growth, its traditionally high unemployment rates, and its also high rates of fixed-term and informal employment. Subsequently, we present our hypotheses and the methodology we rely on in order to examine immigrants' responsiveness to regional employment opportunities and their contribution to narrowing regional unemployment disparities. Results and preliminary conclusions close the study. 


\section{Institutional Framework}

\subsection{Spanish Immigration and Migration Policy}

Up to the mid 1970s, Spain had experienced more out-migration than immigration. As shown by Figure 1, immigration grew at a particular fast pace from the mid 1980s onwards despite the restrictions that the 'Aliens’ Law' of 1985 imposed on non-European Union foreigners in order to establish Spanish residency and citizenship. ${ }^{1}$

\section{[Insert Figure 1]}

Over the 25-year period shown in Figure 1, the number of registered foreigners in Spain multiplied by a factor greater than eight. Various elements steered this trend, such as the country’s democratization, the rapid economic growth in part fueled by Spain’s incorporation to the European Common Market in 1986, the free-entrance of foreigners as tourists together with a lax implementation of immigration laws, and the close linguistic, cultural ties, and preferential treatment to Latin Americans due to colonial history (Escrivá 2000, Ribas-Mateos 2000).

As of today, in spite of augmented immigration restrictions consisting of limited work and residency permit renewals, as well as immigration quotas implemented during the 1990 s, ${ }^{2}$ Spain is considered the most popular port of entry for Latino immigrants (Millman and Vitzthum 2003). Additionally, Spain receives a significant immigrant flow from Africa, particularly Morocco, given its proximity to the Spanish peninsula. Immigrant flows from these two regions have been primarily propelled by the investment of Spanish companies in Latin America, as well as by the political and economic crises in Latin America and Africa

\footnotetext{
${ }^{1}$ One of these restrictions include the need to acquire a work and a residency permit in order to become legal immigrants, along with the granting of 1-year permits to work in a particular activity and geographic location. ${ }^{2}$ Starting in 1993, the Spanish government has been implementing a quota system for agriculture and domestic services. See Escrivá (2000) for greater details.
} 
during much of the 1990s. In this regard, figures 2a through 2d depict the composition of immigrant flows for the main immigrant receiving Spanish regions by immigrants’ continent of origin.

[Insert Figures 2a-2d]

What is the role played by regional labor market conditions in attracting immigrant flows? In particular, do job opportunities serve as immigrant magnets to these regions? Before addressing the aforementioned questions, it is important to highlight some key features of the Spanish labor market.

\subsection{The Spanish Labor Market}

\subsubsection{High Unemployment Rates}

One of the crucial characteristics of the Spanish labor market has been its traditionally high unemployment rate, particularly during the eighties and early nineties. Even as of today, despite the impressive economic growth enjoyed by the Spanish economy, Spain continues to have one of the highest unemployment rates among other OECD countries. Table 1 displays average unemployment rates nationwide as well as by region for three selected years: 1976, 1991 and 2003. Average unemployment rates have remained well above 10 percent since the mid eighties. Moreover, there are very important unemployment rate differences across regions. In particular, while unemployment rates in Navarra, Aragón and La Rioja are below 6.5 percent, Andalucía and Extremadura exhibit double-digits unemployment rates above 15 percent.

[Insert Table 1] 
Do immigrants locate in regions with low unemployment rates? Table 2 displays the regional incidence of immigration. A joint look to the figures in Table 1 and Table 2 reveals that some of the regions with the highest incidence of immigration, such as Cataluña, Valencia, or Andalucía, do not precisely display the lowest unemployment rates. Therefore, at a descriptive level, it is unclear whether immigrants choose to reside in regions offering better employment prospects.

\section{[Insert Table 2]}

\subsubsection{Fixed-term Contracts}

One potential explanation for immigrants' location choice may be the greater availability of suitable and attainable jobs in certain regions regardless of these regions' higher unemployment rates. In this vein, it is important to note the quick spread and current predominance of fixed-term contracts in Spain, which has been deemed a consequence of the political transition from a dictatorship to a democratic political regime underwent after Franco's death in 1975. In the early eighties, coinciding with the economic recession, the vast majority of Spanish workers held indefinite contracts characterized by high dismissal costs. ${ }^{3}$ The need for greater employment flexibility on the part of firms became apparent and, with this purpose, the 1984 reform allowed for the use of fixed-term contracts for employment promotion purposes. The new fixed-term employment contracts offered significant labor cost savings to employers through lower dismissal costs and often lower social security taxes. As such, fixed-term contracts became popular among employers in the midst of growing economic uncertainty and, by the mid eighties, approximately one third of wage and salary 
workers were holding a fixed-term contract. Fixed-term contracts became a right of passage for young workers, who, for the most part, only transited to an indefinite work arrangement upon exhaustion of multiple fixed-term contracts.

In light of the prevailing labor market duality, the major labor reforms of the nineties (1994 and 1997) promoted the use of indefinite work contracts by means of lower dismissal costs. However, as noted by Kugler et al. (2000), the reforms from the nineties had a small impact on the Spanish contractual scenery. As of today, fixed-term contracts continue to account for about one third of the wage and salary workforce. ${ }^{4}$

\subsubsection{Informal Employment}

Another type of flexible work arrangement potentially more accessible to immigrants is informal wage and salary work. For the purpose of this study, we will refer to informal employment as wage and salary work lacking a formal contract. It is "informal" in the sense that it is undeclared to appropriate government authorities and, consequently, unregulated and untaxed. In the absence of a written contract, Spanish employers do not contribute to Social Security and, hence, do not pay any payroll taxes, which amount to approximately 24 percent of an employee's wage. Non-affiliation to the Social Security system comes at a high cost for workers, who are then deprived from a variety of benefits, such as unemployment insurance and retirement pensions. Affiliation to the Social Security is in most cases legally compulsory for employers. ${ }^{5}$ However, Spanish authorities have been quite belligerent with noncompliance to Social Security regulations.

\footnotetext{
${ }^{3}$ Part of the dismissal costs is a severance pay of 45 days' wage per year of seniority in case of a dismissal for economic reasons.

${ }^{4}$ For more information regarding the incidence of fixed-term contracts, see De la Rica (2004).

${ }^{5}$ In a few instances, as is the case with domestic service, compliance with Social Security Regulations is compulsory if the employee works at least 20 hours per week.
} 
As with fixed-term contracts, a better understanding of the Spanish economic environment in the late seventies and early eighties in order to better frame the growth of informal employment. ${ }^{6}$ As stated earlier, in the early eighties Spain was going through a deep recession with increasing labor costs in the form of higher payroll taxes and high dismissal costs for most contracts. Additionally, Spain endured high average inflation rates in the order of 15 percent and a decreasing growth rate of real gross domestic product per capita, which plunged to 1.5 percent after reaching 5.8 percent in the mid seventies. The deep economic recession led to massive plant closures, which raised the unemployment rate from 5.8 percent between 1974 and 1979 to 17.5 percent during the 1980-85 period. Workers displaced from the formal sector became an attractive labor force for firms operating in the underground economy or for firms that, despite being in the formal sector, wanted to reduce labor costs. Firms hiring workers in informal work arrangements avoided high payroll taxes and enjoyed the flexibility of freely dismissing workers when they were no longer needed. This was an attractive feature in the midst of great economic uncertainty and high dismissal costs since, despite being an illegal practice in most cases, the probability of getting caught remained small and the legal framework lacked any criminal disposition for fraud against social security.

Using data from the Spanish Labor Force Survey, we provide an overall portrait of the evolution and magnitude of informal work arrangements in Spain between 1987 and the year 2004 in Table 3. ${ }^{7}$ Despite its decline from the second half of the 1980s thereafter, the figures in Table 3 show how a significant fraction of wage and salary workers continues to lack a written contract.

\footnotetext{
${ }^{6}$ See Lemieux and De la Rica (1994) and Ahn and De la Rica (1997) for more information regarding the reasons underlying the growth and magnitude of the informal sector in Spain during the eighties.

${ }^{7}$ Information on the magnitude of informal employment from the Spanish Labor Force Survey is not available for earlier years.
} 


\section{[Insert Table 3]}

\section{Conceptual Framework}

The migration decision can be viewed as an investment decision. Both natives and foreign-born individuals are income maximizers. As noted by Borjas (2001), migration decisions are guided by the comparison of the present value of lifetime earnings in alternative employment opportunities net of migration costs. If migration costs primarily consist of large fixed costs, many individuals may not find it worth while to migrate. Likewise, if the potential earnings differential across regions is not large enough, many individuals may choose to stay home. However, if most immigrants originate from countries with significantly lower wages (as it may be the case with migrants originating from many African and Latin American nations), the earnings differential between Spain and their home countries is likely to widely exceed any earnings differentials encountered by natives between Spanish regions. In this case, we may observe greater international than internal native migration. After all, natives are likely to encounter smaller earnings differentials across Spanish regions than the ones faced by their immigrant counterparts across countries.

Additionally, once in Spain, foreign-born individuals are likely to exhibit lower migration costs than natives with strong ties to their birth communities. As such, immigrants, and to a lesser extent natives, will choose to reside in the region $r$ where their earnings might be larger. Given the high unemployment rates of some Spanish regions and, even more so, of some groups of less skilled workers, we emphasize the probability of finding employment $(\phi)$ in the individual's final residential choice as follows:

(1) $\phi_{r s} w_{r s}=\max _{j}\left\{\phi_{j s} w_{j s}\right\}$, where: $j=1, \ldots 17$ for each of the seventeen Spanish regions. 
where $w_{r s}$ stands for the wage earned by a person with skills $s$ in region $r$ and $\phi_{r s}$ is the employment likelihood for an individual with those skills in that region. If immigrants from a particular country are likely to contribute similar skills, they will tend to concentrate in regions where their likelihood of finding employment may be greater. Furthermore, the clustering of immigrants in that region will give birth to ethnic enclaves or networks of countrymen, which can significantly increase the likelihood of finding employment and, thus, immigrants' potential earnings in that region.

Summarizing, the described framework has some interesting implications for understanding the high immigration rates and, yet, the low internal mobility of natives in the Spanish case. First, given their lower reservation wages, the relative supply of immigrants to a particular region should exhibit a greater responsiveness to various employment opportunities than the labor supply of natives. Secondly, as immigrants become settled in their host country and assimilate to natives, they may lose some of their responsiveness. Therefore, newer waves of immigrants should be more responsive to job opportunities than older immigrant waves. Alternatively, the possibility exists that very recent immigrants display a lesser responsiveness to regional employment conditions than their older counterparts if migrants choose their first residence on account of other non-employment characteristics, such as whether it was their port of entry into the country. Finally, immigrants may help reduce regional unemployment disparities if they choose to reside in regions with higher employment rates.

\section{Methodology}

\subsection{Are Immigrants More Responsive than Natives to Employment Opportunities?}

Traditional studies relied on regional correlations between the immigration rate and existing labor market conditions to learn about their role in attracting immigrant flows. 
However, this “area approach” strategy has come under criticism, notably by Borjas, Freeman and Katz (1996), Borjas (2001), Card (2001) and more recently Borjas (2003) on two counts. First, because labor market conditions in a particular region could be affected by native inflows and outflows regardless of immigrant flows. If so, how can we measure the impact of labor market conditions on the supply of immigrants relative to natives when labor market conditions are themselves a by-product of ongoing native migration flows? Second, crosssectional analyses may fail to account for demand shocks affecting local labor market conditions and, as such, incite an erroneous interpretation of the correlation coefficients between immigrant flows and labor market conditions.

To lessen any omitted variable biases, we follow the methodology employed by Borjas (2001) in his analysis of the sensitivity of immigrants to regional labor market conditions and make use of a regression analysis using skill groups defined for each year and region as our units of observation ${ }^{8}$. The consideration of skill groups as our unit of observation recognizes that immigrants are a very heterogeneous group. In particular, instead of using the percentage of immigrants in a particular region and period of time as a measure of the competition faced by natives, we assume that natives only compete with immigrants with similar skills. We define each skill group as an age-education cell where both age and education are defined over three categories (age: 30 or less, 31-45, and 45 plus; education: primary education or less, secondary education, and university degree). Therefore, we have nine skill groups. We then measure the supply of immigrants (relative to natives) in a particular region at a point in time for each of the nine age-education groups detailed above with the following index:

\footnotetext{
${ }^{8}$ This methodology has also been used by Carrasco et al. (2004) to measure the effect of Spanish immigration on natives' employment opportunities .
} 
(2) $\quad K_{r s}(t)=\frac{I_{r s}(t) / I_{s}(t)}{N_{r s}(t) / N_{s}(t)}$

where $I_{r s}(t)$ represents the number of immigrants in region $r$ and skill (age-education) group $s$ at period $t$, and $N_{r s}(t)$ represents the number of natives in region $r$ and skill group $s$ at period $t$. Therefore, the index $K_{r s}(t)$ measures the relative supply of immigrants compared to natives in a particular skill group, region, and time period. The index equals 1 when immigrant and native workers of the same skill level have the same geographic distribution, and it is greater than 1 when immigrants in a particular skill group are overrepresented in a particular region at a specific point in time. Since we are working with 17 regions (or Autonomous Communities) and data for 6 years (1999-2004), this supply index is defined over 918 groups (i.e. 17 regions x 6 years $x 9$ skill groups).

Likewise, we measure the supply of recent immigrants relative to immigrants who arrived to Spain at least more than 2 years ago to examine whether the sensitivity to labor market conditions when choosing a region of residence for recent immigrants is any different from the responsiveness exhibited by less recent immigrants. This index is defined as follows:

(3) $\quad K_{r s}^{\prime}(t)=\frac{R I_{r s}(t) / R I_{s}(t)}{N R I_{r s}(t) / N R I_{s}(t)}$

where $R I$ captures the number of recent immigrants and $N R I$ the number of less recent immigrants.

Using the indexes defined above, we first examine whether immigrants are more responsive than natives to regional employment opportunities so as to best understand the high immigration rates and, yet, the low internal mobility of natives in the Spanish case. To the extent that regional employment opportunities and the relative supply of immigrants are likely 
to be simultaneously determined, instrumenting for the existing regional opportunities may be necessary. However, as noted by Borjas (2001), finding a set of valid instruments, that is: (i) highly correlated with regional employment opportunities and (ii) uncorrelated with any of the explanatory variables of the relative supply of immigrants to natives, is virtually impossible. As such, we lag our explanatory variables to at least guarantee their pre-determined character. This model specification is likely to also best reflect how migrants behave. Since migration is an important human capital investment decision, it is reasonable to observe a time lag between the time period to which the regional employment conditions are referred to and immigrant flows.

We estimate three different model specifications, starting with the following OLS regression:

(4) $\quad K_{r s}(t)=\beta\left[E_{r s}(t-1)\right]+\varepsilon_{r s}(t)$

where $E_{r s}(t)$ represents the existing employment opportunities for individuals of skill $s$ in region $r$ at time $t$, and $\varepsilon$ is the disturbance term. Note, however, that equation (4) does not take into account important factors in choosing a final region of residence, such as regional cost-of-living differences, housing shortages, or other region specific factors. Therefore, we subsequently add a number of skill, regional, and year fixed-effects to account for these and other educational, regional and time characteristics possibly driving the relationship between the relative supply of immigrants to natives in a particular cell and their employment possibilities as follows:

$$
K_{r s}(t)=\beta\left[E_{r s}(t-1)\right]+v_{s}+\eta_{r}+\theta_{t}+\varepsilon_{r s}(t)
$$

where $v_{s}$ are skill (age-education) fixed-effects, $\eta_{r}$ are regional fixed-effects, and $\theta_{t}$ are time fixed-effects. As noted by Borjas (2001), equation (5) could still yield spurious relationships 
between regional employment conditions and the location decision of immigrants if immigrants are moving into these regions for reasons unrelated to employment opportunities. However, we can exploit the time variation in the relative responsiveness of immigrants to natives to regional employment conditions and estimate a model that includes interaction terms of skill, region, and time fixed-effects so as to purge out as many spurious correlations as possible as follows:

$$
K_{r s}(t)=\beta\left[E_{r s}(t-1)\right]+\left(v_{s} * \theta_{t}\right)+\left(\eta_{r} * \theta_{t}\right)+\left(v_{s} * \eta_{r}\right)+\varepsilon_{r s}(t)
$$

Equations (4)-(6) are estimated for all immigrants (relative to natives) as well as for our most prominent groups of immigrants: Latino Americans, Europeans, and Africans. We also repeat the analysis using more recent immigrants (relative to not so recent immigrants) in order examine the differential response of immigrants to labor market conditions depending on the length of their residence in Spain.

\subsection{Do Immigrants and Native Enjoy Comparable Employment Opportunities?}

By using skill cells as our unit of observation, we are implicitly assuming that immigrants and natives with the same observed skills (age and education) are exposed to similar employment opportunities regardless of what their final work choices may be in light of their individual reservation wages. This assumption could be debated if immigrants endure specific demand restrictions not borne by natives. As Card (2001) points out, a way to measure the extent to which similarly skilled immigrants and natives are exposed to comparable employment opportunities is to compare their occupational distribution. A similar occupational distribution would suggest that immigrants and natives are exposed to similar labor markets. Therefore, we compute the Duncan Dissimilarity index between immigrants and natives within a given cell to measure occupational segregation as follows: 
(7) $\quad D_{i, n}=\frac{1}{2} \sum_{j=1}^{k}\left|\frac{I_{k}}{I}-\frac{N_{k}}{N}\right|$

where $\frac{I_{k}}{I}$ is the percentage of immigrants in occupation $k$ and $\frac{N_{k}}{N}$ is the percentage of natives in occupation $k$. The index ranges from one (indicating complete segregation) to zero (complete integration), and is read as the proportion of either population that would have to shift employment to generate identical occupational distributions. Table 4 reports the Duncan Dissimilarity Index for each of the nine age-education groups in which we have divided the sample of natives and immigrants. Occupations have been disaggregated at the two-digit International Classification of Occupations. According to the figures in Table 4, immigrants and natives of similar skills are reasonably integrated occupation-wise; despite differences by immigrants' region of origin and skill groups, e.g. $D$ index for Africans in skill group no. 3. Overall, however, it seems reasonable to consider that similarly skilled immigrants and natives in our sample are exposed to comparable labor market opportunities to the extent that their occupational distribution is not very disparate.

[Insert Table 4]

\subsection{Does Immigration Grease the Wheels of the Spanish Labor Market?}

To further address our second question and examine whether the increase in immigration has greased the wheels of the labor market and helped reduce regional disparities in unemployment rates across Spanish regions, we define $U_{r s}(t)$ to measure regional unemployment differences (in absolute terms) with respect to the national average for each skill group: 


$$
U_{r s}(t)=\left|U R_{r s}(t)-U R_{s}(t)\right|
$$

where $U R_{r s}(t)$ is the unemployment rate for individuals in region $r$ and skill group $s$ at time $t$. We then make use of this measure of regional unemployment disparities to examine the extent to which recent immigrant flows may have helped reduce regional unemployment rate differences by means of the following regression model:

(9) $\quad U_{r s}(t)=\beta\left[M_{r s}(t-1)\right]+\varepsilon_{r s}(t)$

where $M_{r s}(t-1)$ is the lagged immigration rate for a particular skill group $s$ in region $r$ at time $(t-1)$. As in the previous section, we estimate alternative specifications of equation (9). First, we include skill, region, and time fixed-effects and, subsequently, we include their interaction terms so as to purge out as many spurious correlations as possible.

\section{Data and Descriptive Evidence}

\subsection{Data}

We use data from the Spanish Labor Force Survey (Encuesta de Población Activa) for the period 1999 through 2004. This survey is administered to approximately 60,000 households on a quarterly basis. For the empirical analysis, we use a pooled cross-sectional database of all active immigrants included in the (second term) survey in any of the years 1999-2004. Our definition of immigrants covers all individuals exclusively reporting a foreign citizenship. We exclude naturalized citizens from our definition of immigrants since questions like the years of residence in the country are only asked to non-naturalized immigrants. The survey offers detailed personal and job characteristics for every interviewed individual, native 
or immigrant. ${ }^{9}$ In addition, for immigrants, the survey collects information on their country of origin as well as on the number of years residing in Spain.

The immigrants included in the Labor Force Survey are all registered households; otherwise, they would have never been interviewed by the survey. Therefore, immigrants in our sample are most likely authorized immigrants, restricting the validity of our inferences to legal immigrants. ${ }^{10}$ At any rate, it is worth noting the representativeness of our data as far as immigrant concentration and distribution is concerned. In this regard, Table 2 displays the distribution of the immigrant population as of the year 2001 according to the 2001 Population Census. Likewise, we show the distribution of our pooled sample of immigrants taken from the 1999-2004 Spanish Labor Force Survey. Despite the different scope of the Population Census and the Labor Force Survey -the Population Census is an individual level survey, whereas the Labor Force Survey is a household based survey stratified by region— both data sources reveal Catalonia and Madrid as the two regions with the highest immigration rates, followed by Andalusia and the Community of Valencia. ${ }^{11}$ In addition, both surveys disclose that Latino Americans, Europeans and Africans account for about 95 percent of all immigrants.

Finally, given our focus on examining the linkage between employment opportunities and the decision to locate in a particular region on the part of natives and immigrants, we restrict our sample to individuals in the workforce. After all, the final location choice of

\footnotetext{
${ }^{9}$ Unfortunately, information on wages is not reported.

${ }^{10}$ Furthermore, until the year 2001, the sampling of immigrants in the Spanish Labor Force Survey was done on the basis of the 1991 Population Census. This changed thereafter as there was a clear agreement on the sampling of immigrants not being representative any longer of the ongoing immigrant stock, which led the Spanish Statistical Institute (INE) to update the sampling procedures on the basis of the 2001 Population Census to guarantee the representativeness of the immigrant sample.

${ }^{11}$ Probably due to the sampling procedures used in the Labor Force Survey, which intents to create a sample stratified by regions, the percentage of immigrants in Madrid may be underrepresented. However, the distribution of immigrants for the remaining regions in the two surveys is fairly similar.
} 
individuals out of workforce is likely to be influenced by characteristics other than labor market opportunities, such as family ties.

\subsection{The Profile of Immigrants and Natives by Skill Group}

The broadest group of our immigrant sample, forty-four percent of either working or unemployed immigrants, comes from Central and South America. Approximately 31 percent originates in Europe and almost 20 percent comes from Africa. Only a small fraction of immigrants varying from 1 to 3 percent originates from North America and Asia, respectively. What are some of the characteristics of natives and immigrants in our sample? Table 5 displays some key features of this population. For instance, immigrants are approximately 3 years younger than similar natives, a slightly higher fraction of immigrants are female relative to natives, and the percentage of household heads is rather similar across the two samples. Interestingly enough, the educational attainment of immigrants and natives seems rather similar judging from their distribution across the primary, secondary and university education categories. Finally, as suspected earlier, a higher fraction of employed immigrants hold fixedterm contracts and informal jobs relative to natives and, if unemployed, endure an unemployment duration about 3 months' shorter than the one experienced by similar natives.

Table 5 also shows the characteristics of immigrants by region of origin. As reflected by the figures, there are notable differences across the three major migrant groups in our sample: Africans, Europeans, and Latino Americans. For instance, only 24 percent of working or unemployed Africans are female relative to 53 of Latino Americans. Additionally, fifty percent of African migrants are household heads, whereas only 39 percent of Latino Americans are heads of households. Another notable difference across these three migrant groups is their average time in Spain. While African and European migrants display a mean 
residence length of 7 years, Latino-American migration appears to be relatively recent, with the average duration of their stay of approximately 3 years. Education-wise, and despite the similarities between natives and immigrants in the first two columns of Table 5, we also find important divergences across immigrant groups depending on their region of origin. More than half of African migrants have no more than a primary education, whereas only 15 and 19 percent of Europeans and Latino Americans fall within that same category. In contrast, only 9 percent of African immigrants have a university degree compared to 26 percent of Spanish natives or 36 percent of Europeans. Lastly, African migrants endure the highest unemployment rate (approximately 24 percent) and the highest rates of fixed-term employment (up to 27 percent relative to 12 percent of natives). Additionally, about one-third of African and Latino-American immigrants hold informal jobs, followed by about one-fourth of Europeans. These percentages compare to 12 percent of natives.

[Insert Table 5]

In addition to learning about the characteristics of our sample of working or unemployed immigrants and natives, it is worthwhile to explore their distribution across the various region-year-skill cells. According to the figures in Table 6, the average cell size is just above 900 , of which on average 3 percent are immigrants. It is worth noting the variation in average unemployment rates across cells, which is in the order of 4 percent. This difference confirms the regional disparity in unemployment rates already displayed by the figures in Table 1.

[Insert Table 6] 


\section{Are Immigrants More Responsive to Employment Opportunities than Natives?}

The first empirical question we want to address is whether immigrants are more responsive to employment opportunities than similarly skilled natives so as to better understand the high immigrant flows and the low internal mobility of natives in the Spanish case. Tables 7a through 7d display the results from estimating the specifications in equations (4)-(6) -labelled [1], [2], and [3] in the tables- using the overall relative immigrant-native supply index, as well as for separate immigrant groups according to their region of origin, i.e. Africa, Europe, and Latin America. Table 8 further reveals the responsiveness to labor market conditions of recent immigrants relative to their more settled counterparts.

All three specifications are estimated using three different measures of employment opportunities, which result in models: A, B, and C. Model A uses the average employment rate for each cell as an indicator of overall employment opportunities. However, to the extent that the average employment rate does not take into account personal characteristics, it may fail to adequately capture the employment opportunities of a given native or immigrant in our sample. Therefore, in Model B, we use the predicted likelihood of being employed for each individual in our sample as an alternative measure of employment opportunities. Lastly, given the disproportionate representation of immigrants in fixed-term and informal work arrangements according to Table 5, Model C uses yet another indicator of existing employment opportunities, such as the predicted likelihood of being employed for each individual included in the sample under a variety of work arrangements. We distinguish among self, indefinite, fixed-term, and informal work. The predicted employment probabilities for being employed as well as for being employed in any of these work arrangements are derived from a multinomial logit model with the following outcomes: (1) unemployment, (2) employment through an 
indefinite-work contract, (3) fixed-term employment, (4) informal work, and (5) selfemployment. The multinomial logit allows us to control for a variety of demographic, regional, and time-specific variables, in addition to immigrants' region of origin and years of residence in Spain possibly affecting their employment likelihood and, thus, location decisions. $^{12}$

The figures in Table 7a reveal that immigrants are more responsive than natives to regional employment opportunities suited to their skills. In fact, their responsiveness increases in magnitude as we account for immigrant and native personal characteristics through their predicted likelihood of being employed in Model B. In particular, immigrants are about twice as responsive as similar natives to a one percentage increase in the predicted probability of finding employment. We also examine the relative responsiveness of immigrants as compared to natives to a variety of employment opportunities in Model C. When we include the most controls, immigrants appear significantly more responsive than their native counterparts to indefinite, self-employment and, in particular, to informal employment opportunities. Why would immigrants be particularly responsive to informal sector work opportunities? Perhaps because natives enjoy the safety nets provided by strong family ties (relative to the weaker ties provided by networks of countrymen in the case of immigrants) as well as unemployment insurance (which immigrants often do not qualify for). Accordingly, natives may be able to avoid an informal work arrangement offering poor working conditions and, instead, afford a longer job search period than similarly skilled immigrants, who instead may be forced to accept the first take-it-or-leave-it offer in order to make ends meet. Overall, the results in

\footnotetext{
${ }^{12}$ The multinomial logit results are displayed in Table A in the appendix. It includes a variety of personal characteristics (such as gender, age, civil status, and a household head dummy), regional level information (such as the incidence of different sectors in the economy), and time dummies to capture any yearly macroeconomic factors.
} 
Table 7a confirm that immigrants locate in regions that provide them with greater employment opportunities, including informal work arrangements viewed as more accessible possibly as a by product of natives’ higher reservation wages for this type of employment.

[Insert Table 7a]

As noted earlier, we re-estimate models A, B, and C for each of their three specifications indicated by equations (4)-(6) and for the three major categories of immigrants in our sample: Latino Americans, Europeans, and Africans. The figures in Tables $7 \mathrm{~b}$ through $7 \mathrm{~d}$ reveal some important differences among immigrants depending on their origin.

Specifically, according to the estimates from specification [3] in Models A, B, and C, Africans and Latino-American immigrants appear significantly more responsive than their native counterparts to larger regional employment rates as well as to higher predicted employment probabilities in informal, self-employment and, lastly, indefinite work. In contrast, European immigrants are only marginally more responsive than their native counterparts to a higher employment probability in informal (about two and a half times more responsive than similar natives) followed by indefinite work arrangements.

[Insert Table 7b-7d]

Table 8 reproduces the estimations in Tables 7a-7d using the relative supply of recent immigrants relative to immigrants with more than 2 years of Spanish residence. The previous literature (e.g. Borjas (2001) has argued that recent immigrants are more responsive than older immigrants to labor market opportunities. If this is the case in Spain, we should observe a differential response from recent (relative to non-recent) immigrants to existing regional 
employment opportunities. However, the figures in Table 8 do not support such a hypothesis. For the most part, recent immigrants appear to behave as immigrants who have lived in Spain longer in terms of their responsiveness to overall regional employment opportunities. This finding could be due to the relatively recent nature of Spanish immigration. With an average length of residence of 5.7 years, we may be unable to find much difference between immigrants with less than 2 years in Spain and their counterparts with 2 years plus. Indeed, it is only with the most complete specification [3] that we find recent immigrants to be less responsive to employment opportunities than their more settled immigrant counterparts. This could result if, for example, new immigrants settle in their port of entry into the country until they find better employment opportunities elsewhere.

\section{[Insert Table 8]}

\section{Does Immigration Help Reduce Regional Unemployment Disparities?}

The analysis of immigrants’ responsiveness to regional labor market conditions as compared to natives is of interest in order to assess whether immigration helps reduce regional labor market disparities. With that intent, we estimate equation (9) using the three specifications labelled [1], [2], and [3] in the previous section. Table 9 displays the results from such exercise. Using our simplest specification (i.e. specification [1]), which excludes any fixed-effects or interaction terms, we observe that higher immigration rates significantly reduce regional unemployment rate differences one year later. This effect disappears as we account for skill, region, and time fixed-effects in specification [2], but resurfaces in our most complete specification (i.e. specification [3]) as we account for any interactive effects between skill, region, and time. As a result, immigration, despite its recent nature, appears to already be 
greasing the wheels of the labor market through the reduction of regional unemployment rate disparities. From a policy perspective, it would be of interest to monitor this effect as immigration continues to grow in order to assess the suitability of a generalized amnesty to past undocumented immigrant flows.

\section{[Insert Table 9]}

\section{Conclusions}

In this paper, we use data from the Spanish labor force survey (Encuesta de Población Activa) for the years 1999 through 2004 to assess the role of regional labor market opportunities in explaining the continuous growth in immigration and the decrease in net interregional flows of the nineties. We thus ask ourselves whether immigrants are more responsive than their native counterparts to regional labor market opportunities. Additionally, we explore whether the recent immigrants flows have helped grease the wheels of the Spanish labor market and reduce regional unemployment disparities.

Following Borjas (2001, 2003) and Card (2003), we estimate various specifications of the impact of regional employment opportunities on the relative supply of immigrants using skill cells as units of observations. Subsequently, we analyze whether the recent immigrant flows have helped reduce regional unemployment disparities as captured by the difference between each region's unemployment rate and the national average for a specific skill group and time period.

Our findings indicate that immigrants choose to reside in regions with higher employment rates and where they enjoy greater employment opportunities, including informal work arrangements viewed as more accessible possibly as a by product of natives' higher 
reservation wages for this type of employment. African and Latin American immigrants appear generally more responsive than their native counterparts to higher employment rates as well as to a higher likelihood of informal, self, or indefinite employment. In contrast, European immigrants are only more responsive than their native counterparts to a higher likelihood of informal and indefinite employment. More importantly, insofar the vast majority of immigrants locate in regions characterized by higher employment rates, immigrant flows appear to contribute to narrowing regional unemployment rate disparities despite the recent nature of immigration in Spain. From a policy perspective, our findings hint on the potential for policies favouring immigration and the assimilation of new immigrant waves in helping “redistribute” mobile workers towards regions with lower unemployment rates and, as such, allow for a reduction of labor market disparities across Spanish regions. 


\section{References}

Ahn, Namkee and Sara De la Rica. (1997). "Underground Economy in Spain: An alternative to unemployment?” Applied Economics, 29(6): 733-743.

Bentolila, Samuel and Olivier Blanchard. (1990). “Spanish Unemployment”, Economic Policy: A European Forum, 0(10): 233-81.

Bentolila, Samuel and Juan J. Dolado. (1991). "Mismatch and Internal Migration in Spain, 1962-86” in Mismatch and Labour Mobility, Cambridge; New York and Melbourne:

Cambridge University Press.

Bentolila, Samuel. (1997). “La Inmovilidad del Trabajo en las Regiones Españolas” Papeles de Economía Española, 72.

Bentolila, Samuel. (2002). “Las Migraciones Interiores en España”, Mercado de Trabajo, Immigración y Estado del Bienestar, Chapter 6, FEDEA

(ftp://ftp.fedea.es/pub/inmigra/parte6.pdf).

Borjas, George J., Freeman, Richard B., and Lawrence Katz. (1996). "Searching for the Effects of Immigration on the Labor Market”, American Economic Review, 86(2): 246-251.

Borjas, George J. (2001). “Does Immigration Grease the Wheels of the Labor Market?” Brookings Papers on Economic Activity, 0(1): 69-119.

Borjas, George J. (2003). “The Labor Demand Curve is Downward Sloping: Reexamining the impact of immigration on the Labor Market”, The Quarterly Journal of Economics, 118(4): 1335-1374.

Bover, Olympia and Pilar Velilla. (1999). "Migrations in Spain : Historical Background and Current Trends” Banco de España Servicio de Estudios, Documentos de Trabajo: 9909.

Card, David. (2001), "Immigrant Inflows, Native Outflows, and the Local Labor Market Impacts of Higher Immigration”, Journal of Labor Economics, 19(1): 22-64.

Carrasco, Raquel, Juan F. Jimeno-Serrano, and Ana C. Ortega-Masague. (2004). “The Effect of Immigration on the Employment Opportunities of Native-Born Workers: Some Evidence for Spain” FEDEA Working Paper No. 2004-17.

De la Rica, S. (2004). "Wage Gaps between workers with indefinite and fixed-term contracts: The impact of firm and occupational segregation”, Moneda y Crédito, 219, pp: 43-69.

Del Boca, Daniela and Alessandra Venturini. (2003). “Italian Migration” IZA Discussion Paper Series No. 938. 
Escrivá, Angeles. (2000). “The Position and Status of Migrant Women in Spain” in Gender and Migration in Southern Europe: Women on the Move, edited by Flova Anthias and Gabriella Lazaridis, Oxford and New York: Berg, pp. 199-225.

Lemieux, Thomas and Sara De la Rica (1994). "Does Public Health Insurance Reduce labor market flexibility or encourage the underground economy? Evidence from Spain and the United States" in Social Protection versus Economic Flexibility: Is there a trade off? ed. Rebecca Blank, NBER.

Millman, Joel and Carlta Vitzthum. (2003). “Changing Tide: Europe Becomes New Destination for Latino Workers”, The Wall Street Journal, September 12, 2003.

Ribas-Mateos, Natalia. (2000). “Female Birds of Passage: Leaving and Settling in Spain” in Gender and Migration in Southern Europe: Women on the Move, edited by Flova Anthias and Gabriella Lazaridis, Oxford and New York: Berg, pp. 173-197. 
Figure 1

Evolution of Immigrant Flows as a \% of the Spanish Population (1975-2003)

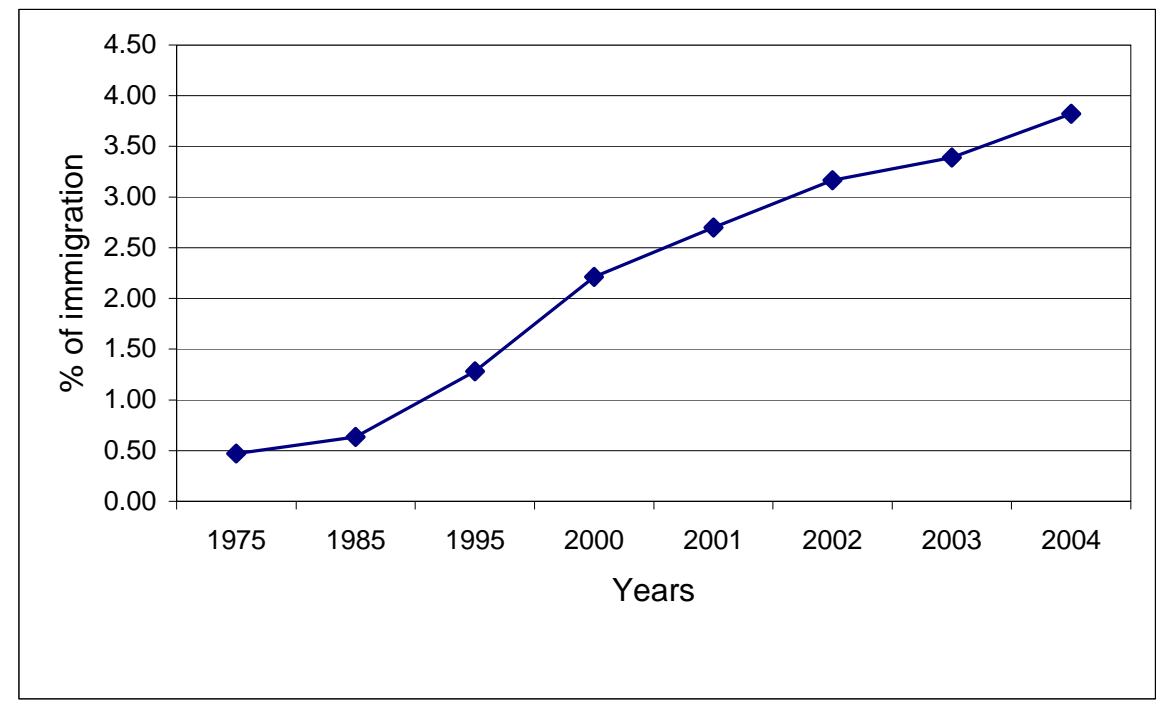



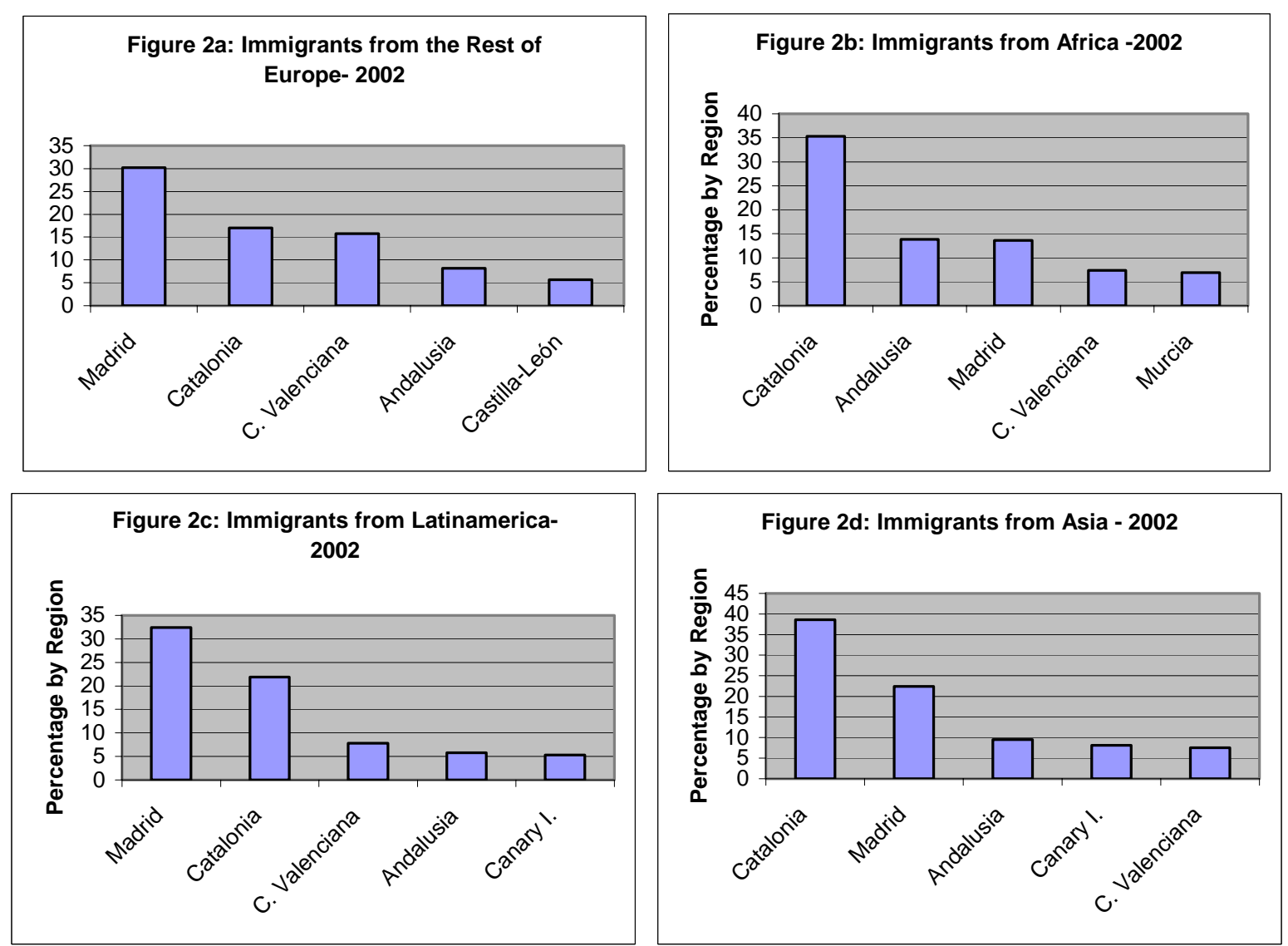

Source: Anuario de Extranjería, 2002. 
Table 1

Regional Unemployment Rates for Selected Years

\begin{tabular}{lccc}
\hline \multirow{2}{*}{ Regions } & \multicolumn{3}{c}{ Years } \\
\cline { 2 - 4 } & $\mathbf{1 9 7 6}$ & $\mathbf{1 9 9 1}$ & $\mathbf{2 0 0 3}$ \\
\hline Andalucia & 9.35 & 24.47 & 18.17 \\
Aragón & 2.54 & 9.37 & 6.48 \\
Asturias & 3.08 & 15.69 & 10.74 \\
Balears & 3.32 & 8.5 & 9.18 \\
Canary Islands & 8.55 & 24.49 & 11.56 \\
Cantabria & 2.78 & 15.25 & 10.48 \\
Castilla and León & 2.69 & 14.5 & 11.19 \\
Castilla-La Mancha & 4.57 & 13.71 & 9.74 \\
Catalonia & 3.46 & 11.68 & 9.37 \\
Extremadura & 4.27 & 24.32 & 16.51 \\
Galicia & 1.56 & 12.56 & 11.85 \\
Madrid & 4.66 & 11.26 & 7.01 \\
Murcia & 4.77 & 16.59 & 9.56 \\
Navarra & 3.94 & 10.24 & 5.15 \\
País Vasco & 3.45 & 18.7 & 9 \\
Rioja & 1.63 & 9.26 & 5.58 \\
Valencia & 3.23 & 15.78 & 10.94 \\
Country Average & $\mathbf{4 . 4 1}$ & $\mathbf{1 5 . 8 8}$ & $\mathbf{1 1 . 2}$ \\
\hline
\end{tabular}


Table 2

Immigrant Distribution Across Spanish Regions and from Place of Origin

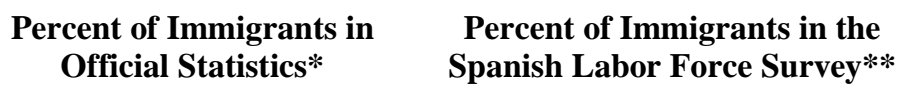

\section{Across Spanish Regions}

Andalucia

11.36

Balears

Canary Islands

Castilla-León

Catalonia

Galicia

Madrid

Murcia

Valencia

Rest of regions

Total

By Continent of Origin

Africa

Asia

Europe

Latin America

Oceania and others

Total
4.41

6.28

2.36

19.6

2.22

23.41

4.41

13.92

12.03

100

21.2

4.6

34.02

39.90

3.28

100
8.13

7.50

10.21

6.41

15.63

4.25

11.29

5.00

13.82

17.76

100

18.5

3.1

31.4

44.9

2.14

100

Sources: (*) 2001 Population Census. (**) Spanish Labor Force survey, 1999-2004. 
Table 3

Incidence of Informal Work Among Wage and Salary Workers (\%)

\begin{tabular}{lcc}
\hline Years & $\mathbf{1 9 9 9}$ & $\mathbf{2 0 0 3}$ \\
\hline Average & $\mathbf{1 7 . 8}$ & $\mathbf{1 4 . 7 4}$ \\
By Educational Attainment & & \\
Primary or less & 14.62 & 12.92 \\
Secondary & 20.64 & 16.35 \\
University & 13.59 & 12.71 \\
By Age & & \\
16-24 & 40.2 & 32.7 \\
25-34 & 23.6 & 19.2 \\
35-49 & 10.1 & 9.53 \\
By Gender & & \\
Males & 15.5 & 11.6 \\
Females & 21.8 & 19.3 \\
\hline
\end{tabular}

Source: Spanish Labor Force Survey (EPA), second quarter. Information about informal work arrangements is not provided for previous years. 
Table 4

Duncan Dissimilarity Index for Immigrants and Natives within Skill Groups

\begin{tabular}{|c|c|c|c|c|}
\hline \multirow[t]{2}{*}{ Skill Groups } & Total Immigration & Europ. Immigration & Afric. Immigration & L.Amer. Immigration \\
\hline & Natives & Natives & Natives & Natives \\
\hline 1 & 0.326 & 0.214 & 0.332 & 0.420 \\
\hline 2 & 0.346 & 0.198 & 0.403 & 0.346 \\
\hline 3 & 0.384 & 0.252 & 0.694 & 0.346 \\
\hline 4 & 0.259 & 0.186 & 0.248 & 0.379 \\
\hline 5 & 0.327 & 0.169 & 0.286 & 0.323 \\
\hline 6 & 0.355 & 0.239 & 0.376 & 0.342 \\
\hline 7 & 0.357 & 0.284 & 0.324 & 0.447 \\
\hline 8 & 0.306 & 0.253 & 0.263 & 0.327 \\
\hline 9 & 0.398 & 0.338 & 0.287 & 0.432 \\
\hline
\end{tabular}

Notes: Skill groups are defined in terms of three age groups (less than 30, 31-45 and more than 45) and three educational levels: primary or less, secondary and university studies. The Duncan Dissimilarity Index is defined as:

$D_{i, n}=\frac{1}{2} \sum_{j=1}^{k}\left|\frac{I_{k}}{I}-\frac{N_{k}}{N}\right|$, where $\frac{I_{k}}{I}$ and $\frac{N_{k}}{N}$ are the percentage of immigrants and natives in occupation $k$, respectively. 
Table 5

Means and Standard Deviations of Key Characteristics of Natives and Immigrants in the Labor Force

\begin{tabular}{|c|c|c|c|c|c|}
\hline Variables & Natives & Immigrants & Africans & Europeans & $\begin{array}{c}\text { Latino } \\
\text { Americans }\end{array}$ \\
\hline Female & $\begin{array}{c}0.40 \\
(0.49)\end{array}$ & $\begin{array}{c}0.43 \\
(0.49)\end{array}$ & $\begin{array}{c}0.24 \\
(0.42)\end{array}$ & $\begin{array}{c}0.43 \\
(0.49)\end{array}$ & $\begin{array}{c}0.53 \\
(0.50)\end{array}$ \\
\hline Age & $\begin{array}{c}38.34 \\
(11.98)\end{array}$ & $\begin{array}{c}35.26 \\
(10.20)\end{array}$ & $\begin{array}{l}33.41 \\
(9.44)\end{array}$ & $\begin{array}{c}36.89 \\
(10.65)\end{array}$ & $\begin{array}{l}34.65 \\
(9.76)\end{array}$ \\
\hline Head of household & $\begin{array}{c}0.43 \\
(0.50)\end{array}$ & $\begin{array}{c}0.44 \\
(0.50)\end{array}$ & $\begin{array}{c}0.50 \\
(0.50)\end{array}$ & $\begin{array}{c}0.47 \\
(0.50)\end{array}$ & $\begin{array}{c}0.39 \\
(0.49)\end{array}$ \\
\hline Married & $\begin{array}{c}0.58 \\
(0.49)\end{array}$ & $\begin{array}{c}0.56 \\
(0.50)\end{array}$ & $\begin{array}{c}0.53 \\
(0.50)\end{array}$ & $\begin{array}{c}0.59 \\
(0.49)\end{array}$ & $\begin{array}{c}0.54 \\
(0.50)\end{array}$ \\
\hline Years of residence & - & $\begin{array}{c}5.73 \\
(6.74)\end{array}$ & $\begin{array}{c}6.88 \\
(5.79)\end{array}$ & $\begin{array}{c}7.29 \\
(8.28)\end{array}$ & $\begin{array}{c}3.37 \\
(4.16)\end{array}$ \\
\hline \multicolumn{6}{|l|}{ Education } \\
\hline Primary or less & $\begin{array}{c}0.25 \\
(0.43)\end{array}$ & $\begin{array}{c}0.24 \\
(0.43)\end{array}$ & $\begin{array}{c}0.55 \\
(0.50)\end{array}$ & $\begin{array}{c}0.15 \\
(0.35)\end{array}$ & $\begin{array}{c}0.19 \\
(0.39)\end{array}$ \\
\hline Secondary & $\begin{array}{c}0.49 \\
(0.50)\end{array}$ & $\begin{array}{c}0.50 \\
(0.50)\end{array}$ & $\begin{array}{c}0.36 \\
(0.48)\end{array}$ & $\begin{array}{c}0.50 \\
(0.50)\end{array}$ & $\begin{array}{c}0.57 \\
(0.49)\end{array}$ \\
\hline University & $\begin{array}{c}0.26 \\
(0.44)\end{array}$ & $\begin{array}{c}0.25 \\
(0.43)\end{array}$ & $\begin{array}{c}0.09 \\
(0.28)\end{array}$ & $\begin{array}{c}0.36 \\
(0.48)\end{array}$ & $\begin{array}{c}0.24 \\
(0.43)\end{array}$ \\
\hline \multicolumn{6}{|l|}{ Work Status } \\
\hline Employed & $\begin{array}{c}0.85 \\
(0.36)\end{array}$ & $\begin{array}{c}0.83 \\
(0.38)\end{array}$ & $\begin{array}{c}0.76 \\
(0.43)\end{array}$ & $\begin{array}{c}0.86 \\
(0.34)\end{array}$ & $\begin{array}{c}0.83 \\
(0.37)\end{array}$ \\
\hline Unemployed & $\begin{array}{c}0.15 \\
(0.36)\end{array}$ & $\begin{array}{c}0.17 \\
(0.38)\end{array}$ & $\begin{array}{c}0.24 \\
(0.43)\end{array}$ & $\begin{array}{c}0.14 \\
(0.34)\end{array}$ & $\begin{array}{c}0.17 \\
(0.37)\end{array}$ \\
\hline Self-employed workers & $\begin{array}{c}0.19 \\
(0.39)\end{array}$ & $\begin{array}{c}0.13 \\
(0.34)\end{array}$ & $\begin{array}{c}0.08 \\
(0.27)\end{array}$ & $\begin{array}{c}0.19 \\
(0.39)\end{array}$ & $\begin{array}{c}0.09 \\
(0.28)\end{array}$ \\
\hline Workers with indefinite contracts & $\begin{array}{c}0.54 \\
(0.50)\end{array}$ & $\begin{array}{c}0.37 \\
(0.48)\end{array}$ & $\begin{array}{c}0.30 \\
(0.46)\end{array}$ & $\begin{array}{c}0.38 \\
(0.49)\end{array}$ & $\begin{array}{c}0.38 \\
(0.49)\end{array}$ \\
\hline Workers with fixed-term contracts & $\begin{array}{c}0.12 \\
(0.33)\end{array}$ & $\begin{array}{c}0.18 \\
(0.39)\end{array}$ & $\begin{array}{c}0.27 \\
(0.44)\end{array}$ & $\begin{array}{c}0.17 \\
(0.37)\end{array}$ & $\begin{array}{c}0.17 \\
(0.38)\end{array}$ \\
\hline Workers with informal jobs & $\begin{array}{c}0.12 \\
(0.33)\end{array}$ & $\begin{array}{c}0.29 \\
(0.45)\end{array}$ & $\begin{array}{c}0.32 \\
(0.47)\end{array}$ & $\begin{array}{c}0.24 \\
(0.43)\end{array}$ & $\begin{array}{c}0.33 \\
(0.47)\end{array}$ \\
\hline Unemployment duration (in months) & $\begin{array}{l}23.33 \\
(5.41)\end{array}$ & $\begin{array}{l}20.53 \\
(5.44)\end{array}$ & $\begin{array}{l}19.86 \\
(4.60)\end{array}$ & $\begin{array}{l}20.73 \\
(5.70)\end{array}$ & $\begin{array}{l}20.65 \\
(5.60)\end{array}$ \\
\hline Observations & 431,520 & 10,931 & 2,024 & 3,428 & 4,910 \\
\hline
\end{tabular}

Note: Standard deviations in brackets. 
Table 6

Distribution of Region-Skill Cells

\begin{tabular}{|c|c|c|c|c|}
\hline Characteristics & Mean & $\begin{array}{l}\text { Standard } \\
\text { Deviation }\end{array}$ & $\begin{array}{c}\text { Smallest } \\
1 \% \\
\text { Percentile }\end{array}$ & $\begin{array}{c}\text { Largest } \\
99 \% \\
\text { Percentile }\end{array}$ \\
\hline Average cell size & 922.20 & 654.99 & 7 & 3245 \\
\hline Percentage of immigrants & 2.47 & 3.08 & 0 & 68.75 \\
\hline$U_{j c}$ & 4.63 & 3.74 & 0.01 & 28.33 \\
\hline Employment rate & 84.65 & 8.90 & 50 & 100 \\
\hline Unemployment rate & 15.35 & 8.90 & 0 & 50 \\
\hline Average unemployment duration & 22.93 & 5.64 & 8.82 & 38.89 \\
\hline Percentage of self-employed workers & 15.99 & 9.47 & 0 & 45.98 \\
\hline Percentage of workers with indefinite contracts & 48.14 & 16.83 & 7.41 & 93.46 \\
\hline Percentage of workers with fixed-term contracts & 11.06 & 6.23 & 0 & 57.14 \\
\hline Percentage of workers with informal jobs & 11.27 & 7.94 & 0 & 50.46 \\
\hline Percentage of workers employed in agriculture & 7.14 & 7.46 & 0 & 42.39 \\
\hline Percentage of workers employed in construction & 12.73 & 6.47 & 0 & 70 \\
\hline Percentage of workers employed in trade & 11.10 & 4.05 & 0 & 37.5 \\
\hline Percentage of workers employed in hotels & 6.96 & 4.02 & 0 & 66.67 \\
\hline Percentage of workers employed in domestic services & 2.83 & 2.11 & 0 & 28.57 \\
\hline Observations & \multicolumn{4}{|c|}{918} \\
\hline
\end{tabular}


Table $7 a$

Immigrant vs. Native Responsiveness to Employment Opportunities

Dependent Variable: $\left(K_{j c}(t)\right)$ - OLS estimation

\begin{tabular}{|c|c|c|c|c|c|c|c|c|c|}
\hline \multirow{2}{*}{ Independent Variables } & \multicolumn{3}{|c|}{ Model A } & \multicolumn{3}{|c|}{ Model B } & \multicolumn{3}{|c|}{ Model C } \\
\hline & [1] & [2] & [3] & [1] & [2] & [3] & [1] & [2] & [3] \\
\hline Employment Rate in t-1 & $\begin{array}{c}0.027 * * * \\
(0.002)\end{array}$ & $\begin{array}{c}0.014 * * * \\
(0.005)\end{array}$ & $\begin{array}{c}0.020 * * * \\
(0.005)\end{array}$ & & - & & - & - & \\
\hline Predicted Employed Probability in $t-1$ & - & - & - & $\begin{array}{c}2.53 * * * \\
(0.25)\end{array}$ & $\begin{array}{c}1.22 * * * \\
(0.52)\end{array}$ & $\begin{array}{c}1.99 * * * \\
(0.42)\end{array}$ & - & - & \\
\hline Predicted Indefinite Work Probability in $t-1$ & - & - & - & - & - & - & $\begin{array}{c}5.10^{* * * *} \\
(0.49)\end{array}$ & $\begin{array}{c}1.26 * * * \\
(0.54)\end{array}$ & $\begin{array}{c}3.91 * * * \\
(0.78)\end{array}$ \\
\hline Predicted Fixed-term Work Probability in $t-1$ & - & - & - & - & - & - & $\begin{array}{c}4.12^{* * *} \\
(1.44)\end{array}$ & $\begin{array}{c}-3.65^{* *} \\
(2.05)\end{array}$ & $\begin{array}{c}2.01 \\
(2.53)\end{array}$ \\
\hline Predicted Informal Work Probability in $t-1$ & - & - & - & - & - & - & $\begin{array}{c}9.37 * * * \\
(0.72)\end{array}$ & $\begin{array}{c}4.74 * * * \\
(1.34)\end{array}$ & $\begin{array}{c}11.05^{* * *} \\
(1.91)\end{array}$ \\
\hline Predicted Probability of Self-employment in $t-1$ & - & - & - & - & - & - & $\begin{array}{c}3.53^{* * *} \\
(0.67)\end{array}$ & $\begin{array}{c}0.83 \\
(0.84)\end{array}$ & $\begin{array}{c}5.47^{* * *} \\
(1.18)\end{array}$ \\
\hline Skill, Region and Year Effects & No & Yes & No & No & Yes & No & No & Yes & No \\
\hline Fully Interacted Skill, Region and Year Effects & No & No & Yes & No & No & Yes & No & No & Yes \\
\hline No. of observations & 765 & 765 & 765 & 763 & 763 & 763 & 763 & 763 & 763 \\
\hline
\end{tabular}

Notes: The unit of observation is the region-skill-year cell. Each of the independent variables are averages over each of the cells. Standard errors (in parentheses) are robust to heterogeneity. All estimations are weighted by cell size. There are 16 region controls, 8 skill controls (defined over three age categories and three educational categories) and 4 year controls. *** Signifies statistically different from zero at the $1 \%$ level or better, **at the $5 \%$ level or better and *at the $10 \%$ level or better. 
Table $7 \mathrm{~b}$

African Immigrant vs. Native Responsiveness to Employment Opportunities

Dependent Variable: $\left(K_{j c}(t)\right)$ - OLS estimation

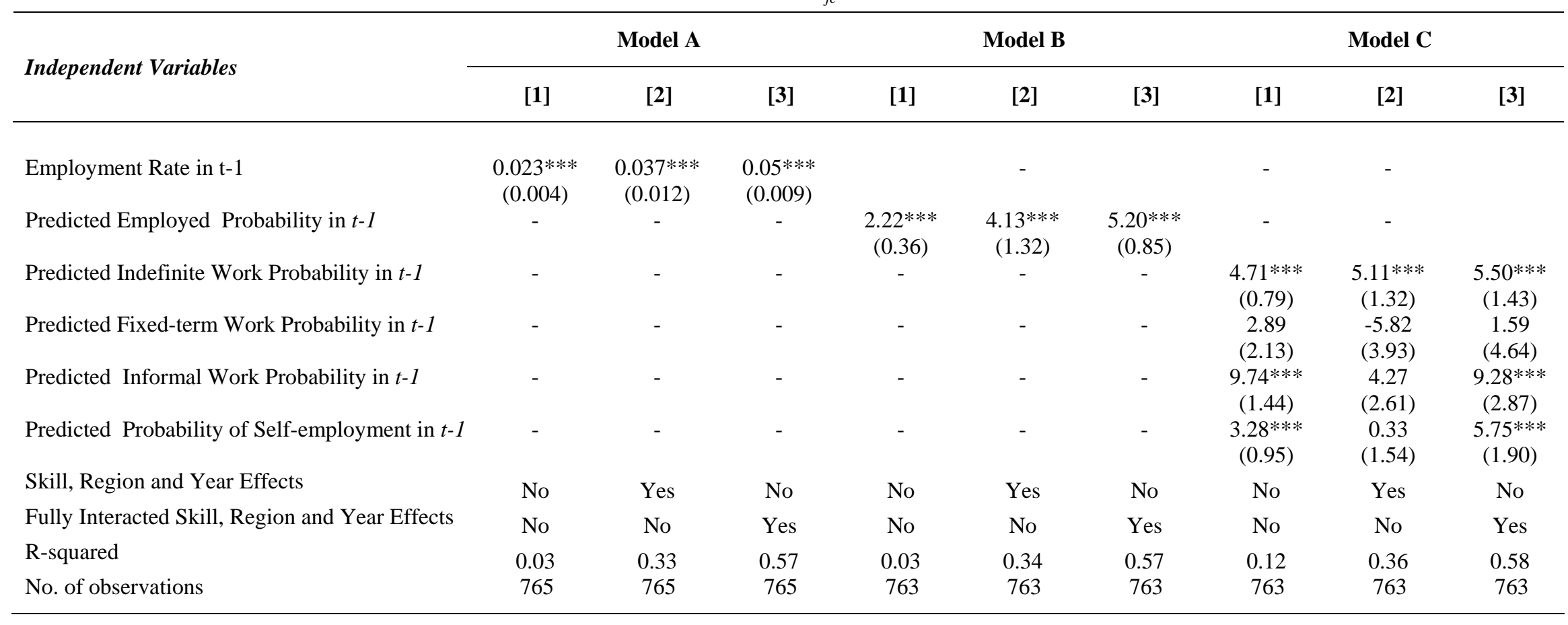

Notes: The unit of observation is the region-skill-year cell. Each of the independent variables are averages over each of the cells. Standard errors (in parentheses) are robust to heterogeneity. All estimations are weighted by cell size. There are 16 region controls, 8 skill controls (defined over three age categories and three educational categories) and 4 year controls. *** Signifies statistically different from zero at the $1 \%$ level or better, **at the $5 \%$ level or better and *at the $10 \%$ level or better. 
Table 7c

European Immigrant vs. Native Responsiveness to Employment Opportunities

Dependent Variable: $\left(K_{j c}(t)\right)$ - OLS estimation

\begin{tabular}{|c|c|c|c|c|c|c|c|c|c|}
\hline \multirow{2}{*}{ Independent Variables } & \multicolumn{3}{|c|}{ Model A } & \multicolumn{3}{|c|}{ Model B } & \multicolumn{3}{|c|}{ Model C } \\
\hline & [1] & [2] & [3] & [1] & [2] & [3] & [1] & [2] & [3] \\
\hline Employment Rate in t-1 & $\begin{array}{c}0.011 * * * \\
(0.003)\end{array}$ & $\begin{array}{l}-0.001 \\
(0.007)\end{array}$ & $\begin{array}{c}0.006 \\
(0.004)\end{array}$ & & - & & - & - & \\
\hline Predicted Employed Probability in $t-1$ & - & - & - & $\begin{array}{c}0.95^{* * *} \\
(0.30)\end{array}$ & $\begin{array}{c}-1.39 * * \\
(0.66)\end{array}$ & $\begin{array}{c}0.46 \\
(0.37)\end{array}$ & - & - & \\
\hline Predicted Indefinite Work Probability in $t-1$ & - & - & - & - & - & - & $\begin{array}{c}1.65^{* * *} \\
(0.54)\end{array}$ & $\begin{array}{c}-2.27 * * * \\
(0.69)\end{array}$ & $\begin{array}{l}1.06^{*} \\
(0.60)\end{array}$ \\
\hline Predicted Fixed-term Work Probability in $t-1$ & - & - & - & - & - & - & $\begin{array}{c}1.22 \\
(1.29)\end{array}$ & $\begin{array}{c}-8.69 * * * \\
(2.33)\end{array}$ & $\begin{array}{l}-0.78 \\
(1.44)\end{array}$ \\
\hline Predicted Informal Work Probability in $t-1$ & - & - & - & - & - & - & $\begin{array}{c}3.58 * * * \\
(0.84)\end{array}$ & $\begin{array}{l}-1.29 \\
(1.54)\end{array}$ & $\begin{array}{l}2.65 * \\
(1.55)\end{array}$ \\
\hline Predicted Probability of Self-employment in $t-1$ & - & - & - & - & - & - & $\begin{array}{l}1.84^{* *} \\
(0.80)\end{array}$ & $\begin{array}{c}1.18 \\
(1.36)\end{array}$ & $\begin{array}{l}-0.11 \\
(1.07)\end{array}$ \\
\hline Skill, Region and Year Effects & No & Yes & No & No & Yes & No & No & Yes & No \\
\hline Fully Interacted Skill, Region and Year Effects & No & No & Yes & No & No & Yes & No & No & Yes \\
\hline No. of observations & 765 & 765 & 765 & 763 & 763 & 763 & 763 & 763 & 763 \\
\hline
\end{tabular}

Notes: The unit of observation is the region-skill-year cell. Each of the independent variables are averages over each of the cells. Standard errors (in parentheses) are robust to heterogeneity. All estimations are weighted by cell size. There are 16 region controls, 8 skill controls (defined over three age categories and three educational categories) and 4 year controls. *** Signifies statistically different from zero at the $1 \%$ level or better, **at the $5 \%$ level or better and *at the $10 \%$ level or better. 
Table 7d

Latino-American Immigrant vs. Native Responsiveness to Employment Opportunities

Dependent Variable: $\left(K_{j c}(t)\right)$ - OLS estimation

\begin{tabular}{|c|c|c|c|c|c|c|c|c|c|}
\hline \multirow{2}{*}{ Independent Variables } & \multicolumn{3}{|c|}{ Model A } & \multicolumn{3}{|c|}{ Model B } & \multicolumn{3}{|c|}{ Model C } \\
\hline & [1] & [2] & [3] & [1] & [2] & [3] & [1] & [2] & [3] \\
\hline Employment Rate in t-1 & $\begin{array}{c}0.022 * * * \\
(0.003)\end{array}$ & $\begin{array}{c}0.007 \\
(0.005)\end{array}$ & $\begin{array}{c}0.012^{* * *} \\
(0.004)\end{array}$ & & - & & - & - & \\
\hline Predicted Employed Probability in $t-1$ & - & - & - & $\begin{array}{c}2.15^{* * * *} \\
(0.28)\end{array}$ & $\begin{array}{l}0.94 * \\
(0.55)\end{array}$ & $\begin{array}{c}1.24 * * * \\
(0.41)\end{array}$ & - & - & \\
\hline Predicted Indefinite Work Probability in $t-1$ & - & - & - & - & - & - & $\begin{array}{c}3.89 * * * \\
(0.51)\end{array}$ & $\begin{array}{c}1.62 * * * \\
(0.63)\end{array}$ & $\begin{array}{c}3.28 * * * \\
(0.92)\end{array}$ \\
\hline Predicted Fixed-term Work Probability in $t-1$ & - & - & - & - & - & - & $\begin{array}{c}0.72 \\
(1.45)\end{array}$ & $\begin{array}{c}1.09 \\
(2.11)\end{array}$ & $\begin{array}{c}0.29 \\
(1.96)\end{array}$ \\
\hline Predicted Informal Work Probability in $t-1$ & - & - & - & - & - & - & $\begin{array}{c}8.36^{* * *} \\
(0.91)\end{array}$ & $\begin{array}{c}7.17 * * * \\
(1.74)\end{array}$ & $\begin{array}{c}12.93 * * * \\
(3.10)\end{array}$ \\
\hline Predicted Probability of Self-employment in $t-1$ & - & - & - & - & - & - & $\begin{array}{c}2.01 * * * \\
(0.73)\end{array}$ & $\begin{array}{l}-1.32 \\
(0.99)\end{array}$ & $\begin{array}{c}6.32 * * * \\
(1.77)\end{array}$ \\
\hline Skill, Region and Year Effects & No & Yes & No & No & Yes & No & No & Yes & No \\
\hline Fully Interacted Skill, Region and Year Effects & No & No & Yes & No & No & Yes & No & No & Yes \\
\hline No. of observations & 765 & 765 & 765 & 763 & 763 & 763 & 763 & 763 & 763 \\
\hline
\end{tabular}

Notes: The unit of observation is the region-skill-year cell. Each of the independent variables are averages over each of the cells. Standard errors (in parentheses) are robust to heterogeneity. All estimations are weighted by cell size. There are 16 region controls, 8 skill controls (defined over three age categories and three educational categories) and 4 year controls. *** Signifies statistically different from zero at the $1 \%$ level or better, **at the $5 \%$ level or better and $*$ at the $10 \%$ level or better. 
Table 8

Recent Immigrant vs. Non-recent Immigrant Responsiveness to Employment Opportunities

Dependent Variable: $\left(K_{j c}{ }^{\prime}(t)\right)$

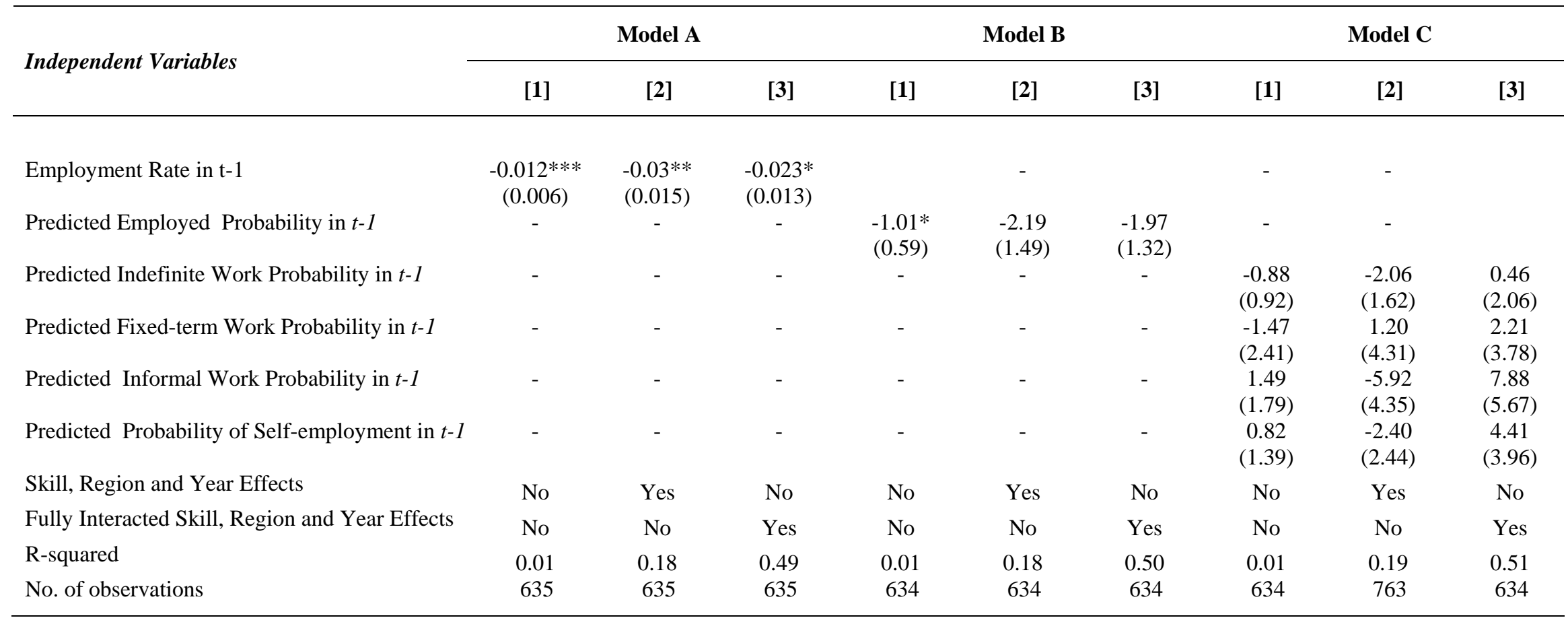

Notes: The unit of observation is the region-skill-year cell. Each of the independent variables are averages over each of the cells. Standard errors (in parentheses) are robust to heterogeneity. All estimations are weighted by cell size. There are 16 region controls, 8 skill controls (defined over three age categories and three educational categories) and 4 year controls. *** Signifies statistically different from zero at the $1 \%$ level or better, **at the $5 \%$ level or better and *at the $10 \%$ level or better. 
Table 9

The Impact of Immigrant Flows on Regional Disparities in Unemployment Dependent Variable: $\left(U_{j c}(t)\right)$

\begin{tabular}{lccc}
\hline Independent Variables & [1] & [2] & [3] \\
\hline Average Immigration Rate at $t-1$ & $-0.117 * * *$ & 0.061 & $-0.124^{*}$ \\
& $(0.04)$ & $(0.04)$ & $(0.07)$ \\
Skill, Region and Year Effects & No & Yes & No \\
Fully Interacted Skill, Region and Year Effects & No & No & 0.77 \\
R-squared & 0.01 & 765 & 765 \\
No. of observations & 765 & & 75 \\
\hline
\end{tabular}

Note: The unit of observation is the region-skill-year cell. Each of the independent variables are averages over each of the cells. Standard errors (in parentheses) are robust to heterogeneity. All estimations are weighted by cell size. There are 16 region controls, 8 skill controls (defined over three age categories and three educational categories) and 4 year controls. *** Signifies statistically different from zero at the $1 \%$ level or better, **at the $5 \%$ level or better and *at the $10 \%$ level or better. 
Table A1: Multinomial Logit Estimation for Work Statuses:

(1) Unemployed, (2) Indefinite Contract, (3) Fixed-Term Contract, (4) Informal, (5) Self-employed

\begin{tabular}{|c|c|c|c|c|}
\hline $\begin{array}{l}\text { Independent } \\
\text { Variables } \\
\end{array}$ & $\begin{array}{c}\text { Indefinite versus } \\
\text { Unemployed }\end{array}$ & $\begin{array}{c}\text { Fixed-Term vs. } \\
\text { Unemployed }\end{array}$ & $\begin{array}{l}\text { Informal vs. } \\
\text { Unemployed }\end{array}$ & $\begin{array}{c}\text { Self-Employed vs } \\
\text { Unemployed }\end{array}$ \\
\hline Female & $\begin{array}{l}-0.786 \\
(0.011)\end{array}$ & $\begin{array}{l}-0.932 \\
(0.01)\end{array}$ & $\begin{array}{l}-0.314 \\
(0.013)\end{array}$ & $\begin{array}{c}-1.26 \\
(0.014)\end{array}$ \\
\hline Age & $\begin{array}{l}-0.001 \\
(0.001)\end{array}$ & $\begin{array}{l}-0.025 \\
(0.002)\end{array}$ & $\begin{array}{l}-0.010 \\
(0.002)\end{array}$ & $\begin{array}{c}0.031 \\
(0.002)\end{array}$ \\
\hline Head of Household & $\begin{array}{c}0.551 \\
(0.017)\end{array}$ & $\begin{array}{c}0.462 \\
(0.021)\end{array}$ & $\begin{array}{c}0.287 \\
(0.021)\end{array}$ & $\begin{array}{c}0.329 \\
(0.022)\end{array}$ \\
\hline Married & $\begin{array}{c}0.393 \\
(0.012)\end{array}$ & $\begin{array}{c}0.145 \\
(0.016)\end{array}$ & $\begin{array}{l}-0.121 \\
(0.016)\end{array}$ & $\begin{array}{c}0.529 \\
(0.015)\end{array}$ \\
\hline Household Size & $\begin{array}{l}-0.064 \\
(0.007)\end{array}$ & $\begin{array}{l}0.0002 \\
(0.008)\end{array}$ & $\begin{array}{l}-0.013 \\
(0.008)\end{array}$ & $\begin{array}{l}-0.083 \\
(0.010)\end{array}$ \\
\hline Secondary Education & $\begin{array}{c}0.561 \\
(0.014)\end{array}$ & $\begin{array}{l}-0.251 \\
(0.017)\end{array}$ & $\begin{array}{c}0.019 \\
(0.017)\end{array}$ & $\begin{array}{c}0.262 \\
(0.016)\end{array}$ \\
\hline University Education & $\begin{array}{c}1.005 \\
(0.016)\end{array}$ & $\begin{array}{l}-0.014 \\
(0.020)\end{array}$ & $\begin{array}{c}0.174 \\
(0.020)\end{array}$ & $\begin{array}{c}0.279 \\
(0.020)\end{array}$ \\
\hline Years of Residence & $\begin{array}{c}0.019 \\
(0.002)\end{array}$ & $\begin{array}{l}-0.010 \\
(0.002)\end{array}$ & $\begin{array}{l}-0.023 \\
(0.001)\end{array}$ & $\begin{array}{c}0.016 \\
(0.002)\end{array}$ \\
\hline Africa & $\begin{array}{l}-0.708 \\
(0.065)\end{array}$ & $\begin{array}{l}-0.452 \\
(0.075)\end{array}$ & $\begin{array}{c}-0.52 \\
(0.072)\end{array}$ & $\begin{array}{l}-0.908 \\
(0.088)\end{array}$ \\
\hline Asia & $\begin{array}{c}0.216 \\
(0.206)\end{array}$ & $\begin{array}{l}-0.504 \\
(0.273)\end{array}$ & $\begin{array}{c}0.029 \\
(0.224)\end{array}$ & $\begin{array}{l}1.347 \\
(0.211)\end{array}$ \\
\hline Central-South America & $\begin{array}{l}-0.208 \\
(0.059)\end{array}$ & $\begin{array}{l}-0.176 \\
(0.071)\end{array}$ & $\begin{array}{c}0.065 \\
(0.064)\end{array}$ & $\begin{array}{l}-0.314 \\
(0.076)\end{array}$ \\
\hline Europe & $\begin{array}{l}-0.122 \\
(0.047)\end{array}$ & $\begin{array}{l}-0.105 \\
(0.058)\end{array}$ & $\begin{array}{l}-0.002 \\
(0.054)\end{array}$ & $\begin{array}{c}0.257 \\
(0.055)\end{array}$ \\
\hline North-America & $\begin{array}{l}-0.328 \\
(0.309)\end{array}$ & $\begin{array}{l}-0.130 \\
(0.413)\end{array}$ & $\begin{array}{l}-0.029 \\
(0.380)\end{array}$ & $\begin{array}{c}0.511 \\
(0.336)\end{array}$ \\
\hline Employment Rate & $\begin{array}{c}0.057 \\
(0.001)\end{array}$ & $\begin{array}{c}0.028 \\
(0.0012)\end{array}$ & $\begin{array}{c}0.019 \\
(0.001)\end{array}$ & $\begin{array}{c}0.044 \\
(0.001)\end{array}$ \\
\hline $\begin{array}{l}\text { Incidence of } \\
\text { Agriculture Sector }\end{array}$ & $\begin{array}{c}0.007 \\
(0.010)\end{array}$ & $\begin{array}{l}-0.027 \\
(0.013)\end{array}$ & $\begin{array}{l}-0.020 \\
(0.013)\end{array}$ & $\begin{array}{c}0.010 \\
(0.011)\end{array}$ \\
\hline Incidence of & 0.0005 & 0.012 & -0.022 & -0.022 \\
\hline Construction Sector & $(0.012)$ & $(0.015)$ & $(0.015)$ & $(0.014)$ \\
\hline Incidence of Industry & -0.014 & 0.008 & -0.032 & -0.009 \\
\hline Sector & $(0.011)$ & $(0.014)$ & $(0.014)$ & $(0.013)$ \\
\hline Incidence of & 0.007 & 0.021 & -0.026 & 0.015 \\
\hline Commerce Sector & $(0.011)$ & $(0.014)$ & $(0.014)$ & $(0.013)$ \\
\hline Incidence of Hotel & 0.009 & 0.005 & -0.036 & 0.022 \\
\hline Sector & $(0.016)$ & $(0.020)$ & $(0.020)$ & $(0.019)$ \\
\hline Incidence of Trade & 0.011 & 0.031 & -0.050 & 0.008 \\
\hline Sector & $(0.015)$ & $(0.020)$ & $(0.020)$ & $(0.018)$ \\
\hline Incidence of Insurance & 0.002 & 0.022 & -0.086 & -0.008 \\
\hline Sector & $(0.024)$ & $(0.032)$ & $(0.031)$ & $(0.030)$ \\
\hline Incidence of Social & -0.011 & -0.022 & -0.037 & -0.035 \\
\hline Sector Services & $(0.012)$ & $(0.016)$ & $(0.016)$ & $(0.015)$ \\
\hline Incidence of Domestic & -0.041 & 0.021 & 0.013 & 0.009 \\
\hline Service Sector & $(0.022)$ & $(0.028)$ & $(0.028)$ & $(0.027)$ \\
\hline Incidence of Other & 0.008 & 0.003 & -0.020 & 0.003 \\
\hline Services & $(0.012)$ & $(0.014)$ & $(0.014)$ & $(0.013)$ \\
\hline
\end{tabular}

Notes: A constant term, regional and year dummies are included. Robust standard errors are in parentheses. 